Historic, Archive Document

Do not assume content reflects current scientific knowledge, policies, or practices. 


\title{
SOUTHERN FORESTS AS A SOURCE OF PULPWOOD
}

\author{
by
}

J. W. Cruikshank

\section{A FOREST SURVEY PROGRESS REPORT}

J. W. Cruikshank, Chief

Division of Forest Economics

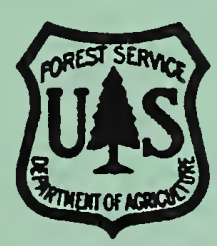

U. S. DEPARTMENT OF AGRICULTURE, FOREST SERVICE

Southeastern Forest Experiment Station

I. T. Haig, Director Asheville, N. C. 


\section{PREFACE}

Through the McSweeny-McNary Act of 1928, Congress authorized the Secretary of Agriculture to conduct a comprehensive survey of the forest resources of the United States. The Forest Survey was organized by the Forest Service to carry out the provisions of the Act, and each of the 11 Regional Forest Experiment Stations is responsible for the work in its territory. In the Southeasterm States the Forest Survey is an activity in the Division of Forest Economics of the Southeastern Forest Experiment Station, Asheville, North Carolina.

The work of the Survey is divided into five major phases:

1. Inventory. Determination of the extent, location, and condition of forest lands, and the quantity, species, and quality of timber on these lands.

2. Growth. Determination of the current rate of timber growth.

3. Drain. Determination of the amount of industrial and domestic wood used, and the total loss resulting from fire, insects, disease, suppression, and other causes.

4. Requirements. Determination of the current and probable future requirements for forest products by all classes of consumers.

5. Policies and plans. Analysis of the relation of these findings to one another and to other economic factors as a basis for public and private policies and plans of forest land use and management.

This progress report summarizes information on the timber resources of the South, with particular emphasis upon pulpwood, and points out ways by which the pulp and paper industry can help in assuring a permanent supply of raw material. 


\title{
SOUTHERN FORESTS AS A SOURCE OF PULPWOOD
}

by

\author{
James W. Cruikshank $2 /$
}

\section{THE REGIONAL TIMBER RESOURCE}

The South, as discussed here, includes the coastal istates extending from the Potomac south to Florida and west to the plains of Texas, plus the inland states of Tennessee, Arkansas, and Oklahoma. Within its boundaries lie almost the entire commercial range of the southern yellow pines and a large part of the Nation's supply of hardwoods. It contains 183 million acres, or 40 percent, of the commercial forest land in the United States and 1.9 billion cords, or 28 percent, of the timber. Practically all is easily accessible by water, rail, or good roads. Even more important from the long-range view, its soils and climate favor rapid timber growth, and year-round logging seasons facilitate timber harvesting.

These advantages are not news to the pulp and paper industry. Today there are 51 mills manufacturing wood pulp with a total daily capacity of 12,900 tons of sulphate fiber, 400 tons of sulphite fiber, 375 tons of soda fiber, and 2,434 tons of semichemical pulp and ground wood. This is onehalf the total U. S. pulp mill capacity. The annual wood requirement of these southern mills is now more than 8 million standard cords, and the demand for pulpwood is constantly increasing as present plants and new plants come into production.

In view of this large and growing demand for pulpwood it is timely to consider the characteristics of the timber resource upon which your industry depends. 'First let us consider the kinds of timber and their general location. Bordering the Atlantic and Gulf coasts from South Carolina to east Texas is the longleaf-slash pine forest (fig. I) of the flat coastal plain, the source of all our gum naval stores. Altogether it covers nearly 35 million acres, two-thirds of which are in Florida and south Georgia. In the Carolinas and Virginia, the loblolly pine is the

1. Presented at the fall meeting of the Technical Association of the Pulp and Paper Industry, Detroit, Mich., Sept. 26-28, 1946. Published in Pulpwood - Stands, Procurement, and Utilization (TAPPI Monograph Series No. 4). 1946.

2) Chief, Division of Forest Economics, Southeastern Forest Experiment Station. 



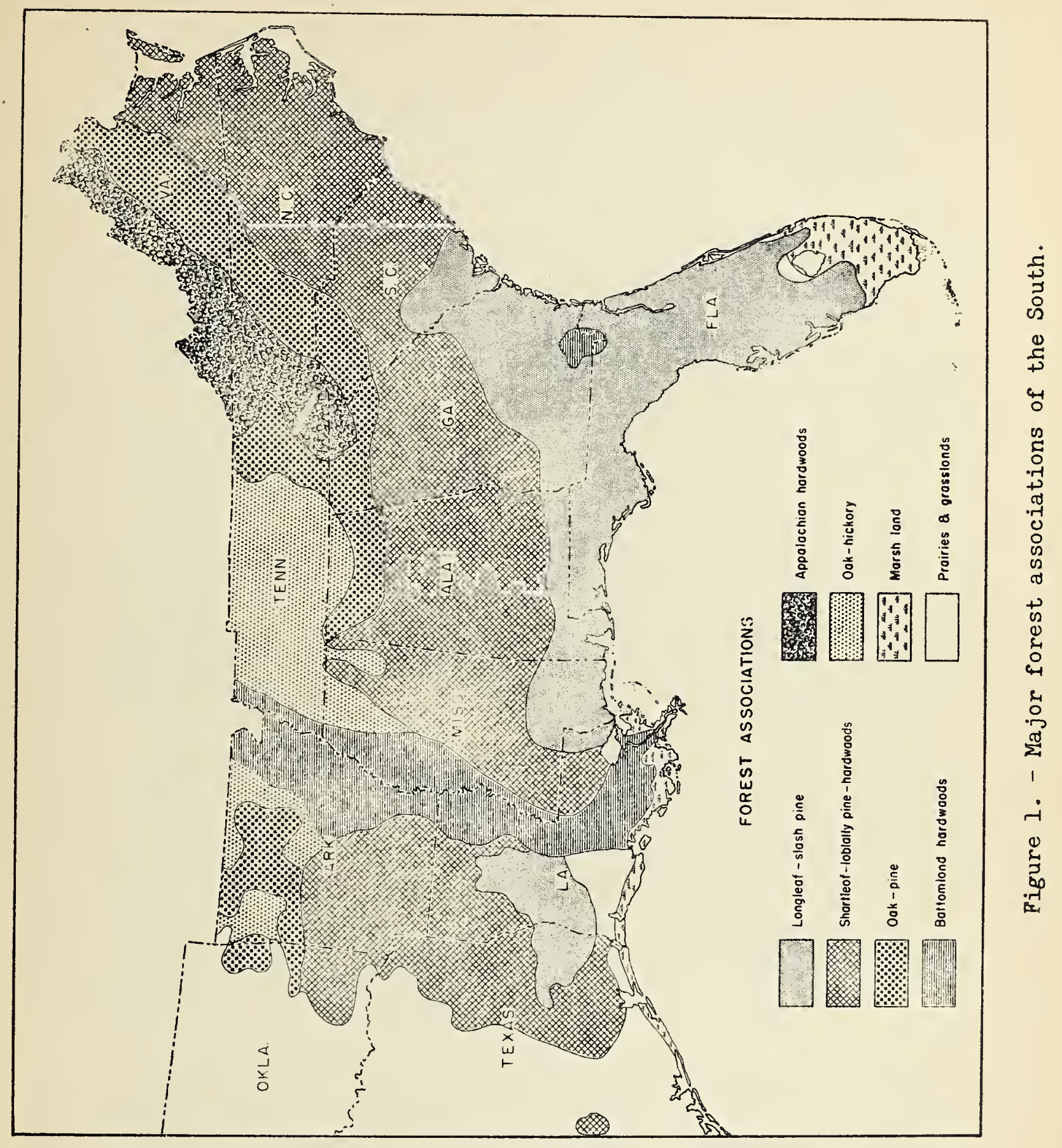



leading species of the coastal plain with shortleaf pine the dominant tree farther inland on the Piedmont. The scrubby and short-lived Virginia pine spreads across all three states in the foothills of the Appalachians and on into north Georgia and Alabama. The separation between loblolly and shortleaf pine is less distinct in the deep South; and the rolling hills of Georgia, Alabama, Mississippi, Louisiana, and Texas are clothed with a mixed loblolly-shortleaf-hardwood forest. Southwestern Arkansas runs heavily to loblolly pine in mixture with hardwoods, but in the mountainous section of the State loblolly is replaced by shortleaf. Tennessee is chiefly a hardwood state, although scattered shortleaf pine is found in the Tennessee Valley, and a narrow belt extends along the western edge of the Appalachians into Kentucky. Altogether, there are nearly 70 million acres of this loblolly-shortleaf-hardwood forest in the region. Other forests, somewhat less important from a pulpwood standpoint, are the Appalachian hardwoods of western North Carolina, Virginia, and north Georgia, the scattered stands of upland hardwoods that break up the continuity of the pine timberlands, the bottomland hardwoods that occur along all of the major rivers, and the broad expanse of Delta hardwoods that occupy the Mississippi flood plain.

When we think of Southern forests, we are almost sure to think of the pines for which it has been famous since earliest colonial times, so it may be somewhat of a surprise to learn that of a total stand of 1.9 billion cords, over 55 percent is hardwood. Softwoods, chiefly the several southern yellow pines, total about 833 million cords. The preponderance of hardwoods is primarily in the smaller tree sizes; hardwood saw timber totals only 144 billion board feet compared to 194 billion feet of pine.

Compared to an annual pulpwood requirement of about 8 million cords, these timber volumes appear very reassuring, apparently indicating a considerable supply of timber for the present and for some time to come. However, pulpwood accounts for only 10 percent of the total cut, and pulpwood producers must compete with other industries for wood. Also, even though 55 percent of the wood in the South is in hardwood species, less than one-tenth of the pulpwood is cut from hardwoods. . Major changes in pulping processes, plant equipment, final product, and wood-procurement practices will be necessary before hardwoods enter strongly into the supply picture.

What we are really concerned with is how much timber can we grow in the South. Present timber volumes give us some indication how we have weathered the transition from virgin timber to second-growth, and they influence the kind and extent of industrial utilization, but for the long pull sound industrial development must be based upon using not more than the annual growth of wood. For the South as a whole, the annual growth totals approximately 50 million cords of softwoods and 44 million cords of hardwoods. Thus, we are growing about one-half cord per average acre per year, but only one-quarter of a cord of the desired softwoods. This is much less than the land is capable of producing, and 

Table 1. - Total quantity of timber in the South, 1945

\begin{tabular}{l|r|r|r|r}
\hline \multicolumn{1}{c|}{ Species group } & \multicolumn{2}{|c|}{ Volume } & \multicolumn{2}{c}{ Air-dry weight } \\
\hline & $\frac{\text { Million }}{\frac{\text { cords }}{4}}$ & Percent & $\frac{\text { Million }}{\text { tons }}$ & Percent \\
Softwoods: & & & & \\
Loblolly pine & 407 & 21 & 512 & 21 \\
Shortleaf pine & 228 & 12 & 288 & 12 \\
Longleaf pine & 89 & 5 & 128 & 5 \\
Slash pine & 60 & 3 & 80 & 3 \\
Cypress & 27 & 1 & 30 & 1 \\
Others & 22 & 1 & 20 & 1 \\
Total & 833 & 43 & 1,058 & 43 \\
Hardwoods: & & & & \\
Red oaks & 250 & 13 & 357 & 14 \\
White oaks & 167 & 9 & 256 & 10 \\
Sweetgum & 200 & 10 & 221 & 9 \\
Tupelo, blackgum & 144 & 7 & 164 & 7 \\
Yellow-poplar & 65 & 3 & 59 & 2 \\
Beech, birch, maples & 28 & 1 & 36 & 1 \\
Others & 262 & 14 & 335 & 14 \\
\cline { 2 - 5 } Total & 1,116 & 57 & 1,428 & 57 \\
\cline { 2 - 5 } & 1,949 & 100 & 2,486 & 100 \\
\hline All species & & & & \\
\hline
\end{tabular}

Note: Cord volumes derived from inside-bark cubic-foot volumes on the basis of 70 cubic feet of softwoods or 65 cubic feet of hardwoods per cord. Species distribution based on sawlog volumes only. 

is also much less than we need if the South is to contribute its share of the wood requirements of a prosperous nation. There is every reason to believe that a major part of the pine land in the South can grow a cord of wood per acre per year. This can eventually be accomplished, but, even with an aggressive forestry program, it will take a number of decades to achieve if we continue at the same time to meet the needs of the forest industries.

One of the major problems to be solved before we can make substantial progress toward increasing the annual yield of wood is to control timber losses from such destructive agencies as fire, insects, and disease. Such losses now amount to 13 million cords annually--60 percent more than the entire cut of pulpwood. Fire is the most important causal agency, and the one most susceptible to control. Porest insects and tree diseases take a toll of both softwoods and hardwoods, but widespread outbreaks are rare. At present, the greatest threat to the softwoods, aside from fire, is the so-called "little-leaf disease" of the shortleaf pine. Already hundreds of thousands of cords of timber have died, and the mortality rate continues unchecked despite the efforts of skilled pathologists seeking the cause and cure. Our objective should be to reduce these fire, insect, and disease losses as rapidly and completely as possible, and use the wood to satisfy the needs of southern people and industries. During recent years there has been a definite and steady industrial development in this region, and there is every indication that this trend will continue at an accelerated rate. This development is reflected in the drain upon the timber stands, which has increased by at least 15 percent during the last decade. In 1944 the total amount of wood cut from southern forests amounted to about 46 million cords of softwoods and 36 million cords of hardwoods, distributed by commodities as follows:

Table 2. - Distribution of commodity drain

\begin{tabular}{l|c|c|c}
\hline \multicolumn{1}{c|}{ Commodity } & Total & Softwoods & Hardwoods \\
\hline & Percent & Percent & Percent \\
Lumber & 51 & 55 & 46 \\
Fuel wood & 21 & 18 & 24 \\
Pulpwood & 10 & 17 & 2 \\
Hewn ties & 6 & 4 & 7 \\
Veneer & 3 & 1 & 7 \\
All other & 9 & 5 & 14 \\
\hline Total & 100 & 100 & 100 \\
\hline
\end{tabular}



What effect have these heavy annual drains had upon the forest growing stock? The latest statistics show that both softwood and hardwood saw timber have decreased about 10 percent in the last decade, the entire softwood growing stock has declined about 3 percent, while the small hardwoods, chiefly of the poor-quality species, have increased considerably faster than they are being utilized. This trend is confirmed by the growth and drain balance for 1944 (table 3), which shows that softwoods decreased by 2.5 million cords while the hardwoods increased by 1.7 million cords. Those whose knowledge of timber conditions extends back over a period of years realize that the change in total volume is only part of the story. Past cutting practices, which selected the better trees of the better species, have resulted in a progressive deterioration in the quality as well as quantity of growing stock. Thus, each year's cut is replaced by inferior growth.

Table 3. - Comparison of annual growth and drain in the South, 1944

\begin{tabular}{|c|c|c|c|c|c|c|}
\hline \multirow{2}{*}{ Item } & \multicolumn{3}{|c|}{$\begin{array}{c}\text { All trees } \\
5 . \text { On }^{\text {d.b.h. \&. larger }}\end{array}$} & \multicolumn{3}{|c|}{ Saw-timber trees } \\
\hline & Total & Softwoods & Hardwoods & Total & Softwoods & Hardwoods \\
\hline & $\frac{\text { Million }}{\text { cords }}$ & $\frac{\text { Million }}{\text { cords }}$ & $\frac{\text { Million }}{\text { cords }}$ & $\frac{\text { Million }}{\text { bd.ft. }}$ & $\frac{\text { Million }}{\text { bd.ft. }}$ & $\frac{\text { Million }}{\text { bd.ft. }}$ \\
\hline Annual growth & $94 \cdot 5$ & 50.3 & $44 \cdot 2$ & 19,949 & 12,923 & 7.026 \\
\hline $\begin{array}{l}\text { Drain: } \\
\text { Fire, disease, } \\
\text { etc. }\end{array}$ & 12.9 & 6.8 & 6.1 & 2,275 & 1,561 & 714 \\
\hline Cutting & 82.4 & 46.0 & 36.4 & 22,627 & 14,077 & 8,550 \\
\hline Total & 95.3 & 52.8 & 42.5 & 24,902 & 15,638 & 9,264 \\
\hline Net change & -0.8 & -2.5 & +1.7 & $-4,953$ & $-2,715$ & $-2,238$ \\
\hline
\end{tabular}



Is there a connection between the declining timber resource and present wood costs and procurement difficulties? I believe there is. Pulpwood procurement men know that theirs is a job which is becoming increasingly difficult. Some can think back 10 years when yellow pine stumpage sold for 75 cents a cord, and pulpwood delivered to the mill cost $\$ 4$. Stumpage now averages about $\$ 2.25$ and the OPA pulpwood price ceiling applicable to most parts of the South is \$9. Ten years ago 15 miles was considered the longest distance over which it was practical to truck pulpwood. Today, 15 miles is just an average haul. Why have these changes occurred?

The immediate answer, of course, is competition. In 1936, there were only $30 \mathrm{pulp}$ mills in the South. Wood fiber production totaled only 1-1/2 million tons. Since that time, 21 new plants have been added, and most of the original ones have expanded. Production this year is expected to exceed 4-3/4 million tons. In other words, your industry has increased its output, and presumably its wood requirements, by 320 percent in 10 years. Reference to a map ( $f^{\circ} i g$. 2) showing pulp mill locations discloses another cause of intensified competition for wood within the industry. It is the tendency to concentrate plant construction in certain localities favored for their supplies of good water and power, nearmess to chemical centers, or availability of barge transportation. There are, for example, six wood pulp mills within 65 miles of Mobile, five in the Jacksonville area, and five east or south of Richmond. Along the ArkansasLouisiana line are seven more, somewhat less closely grouped. Of 12 to 14 new sites proposed, about half either fall in areas already crowded or will create similar problem areas elsewhere. Thus, although some pulpwood is cut in nearly every county of the South, the demand is, and will remain, particularly intense in a few localities. In most cases, it is aggravated by serious over-cutting and consequent reduction of timber stocks。

So much for the competition generated within the pulp and paper industry itself. Of increasingly greater importance is the competition of other forest products industries. Foremost is lumber, which comprises 50 percent of all the drain on the forest resource. Theoretically, pulp and lumber should complement each other, the former preferring trees 8 to 12 inches in diameter or below desirable sawlog size. In recent years, how ever, this balance has been disturbed. Saw timber is becoming increasingly scarce. Except for periods of business depression, over-cutting has continued year after year since the first decade of the century. During the past 10 years alone, the volume of the average pine saw-timber tree has been reduced 25 percent in central Mississippi, 20 percent in southwest Georgia, and 35 percent in central Georgia and northeast Florida. At present, few sizable stands of large timber remain, and portable sawmills moving from one small tract to another account for most of the production. As available tracts become smaller and more scattered, and as the average 



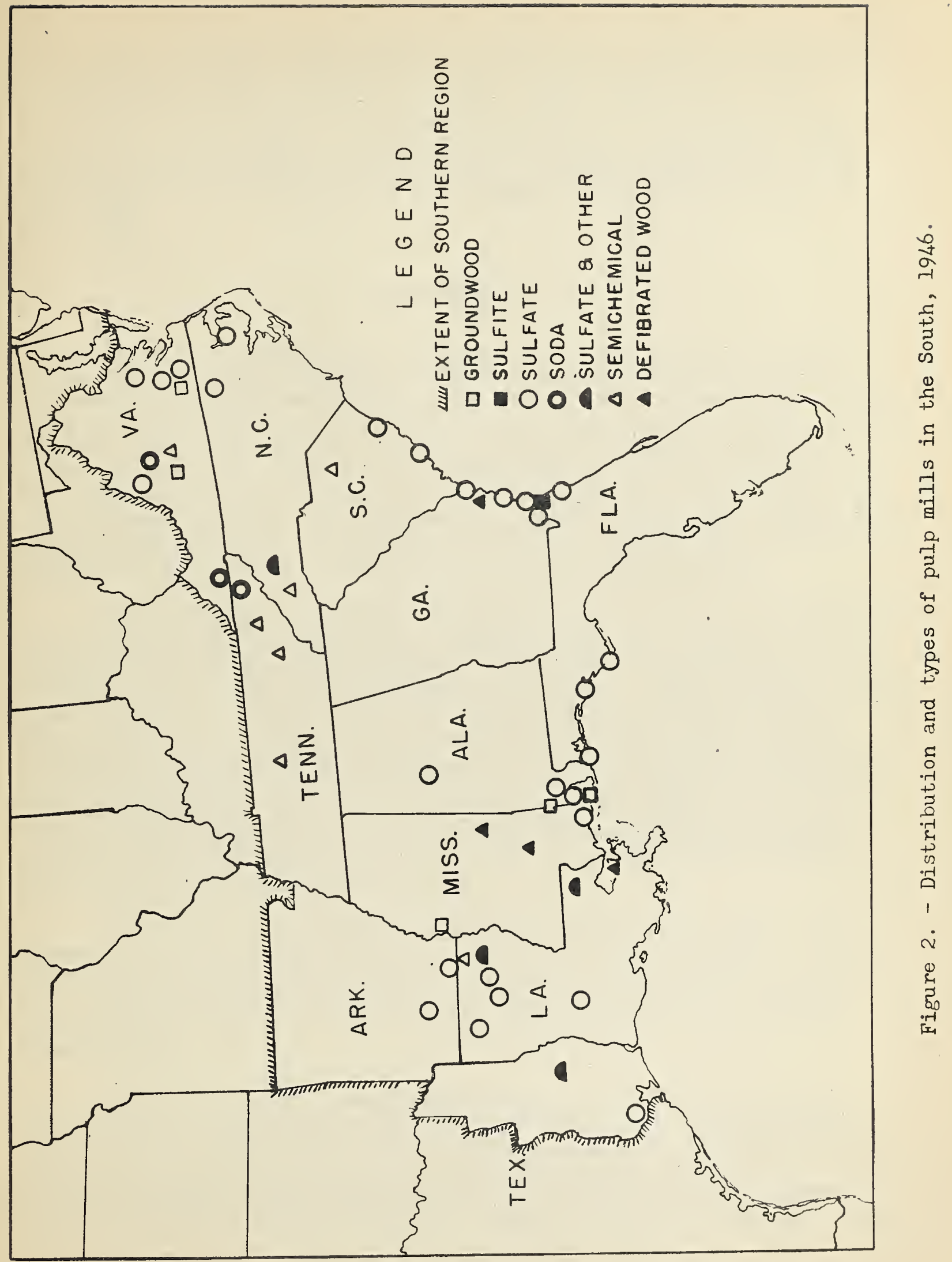



tree size is reduced, the distinction between saw timber and cordwood is gradually losing significance. With a boom market for all types of construction lumber (including low-grade $2 \times 4^{\prime} \mathrm{s}$ ), lumbermen are contracting, in some cases, for yellow pine timber to a six-inch minimum diameter. At prevailing saw-timber prices, this is competition which pulpwood men are unable to meet. Others offering competition in some localities are the producers of small poles, excelsior, and staves for nail kegs.

\section{A I.OOK AHEAD}

No new developments in the pulpwood supply situation are anticipated for the immediate future. Growing stock changes occur slowly; the decline already mentioned has been in progress for many years. The present brisk demand for all forest products may persist many more years. While it lasts, there will be stiff competition for wood between your and other wood-using industries. Indeed, should the lumber market hold up another ten years, the small operators may take an appreciable share of the better quality timber stands you expect to draw upon. Within the pulp and paper industry, competition for wood will be intensified by expansion of existing plant facilities and by new construction.

This problem of gradually tightening competition for a raw material that steadily shrinks both in volume and quality should be a vital concern to all of you with interests in the South. You represent an industry with a large fixed investment in plants. Unlike the small sawmill operator, it cannot afford to pick up those plants and move to fresh territory. Furthermore, the continued success of your industry hinges upon maintaining the advantage of low pulpwood and manufacturing costs it now enjoys over other producing regions. And it is fortunate for the South that this is so, for you and your industry are in a position to take the lead, not only in solving your own wood procurement problems, but in attacking the forest problems of the region. Because, in a real sense, the two are the same.

Your plan of attack might logically include three phases: (1) intensified research, chemical and economic, in the utilization of wood material not now in general demand; (2) forest land acquisition; and (3) a highly organized region-wide program to promote better cutting practices and forest protection, and to increase the productivity of forest land.

The first phase--intensified research in the economic and technical aspects of utilizing hardwoods, cull trees, and logging and manufacturing waste--would be a step toward assuring yourselves an ample supply of raw material at a price little affected by competition. There is, for instance, nearly two million cords per year excess of hardwood growth over drain, mostly in trees of convenient size for pulping. Also 

available are 300 million cords of sound material in hardwood cull trees. Practically its only present use is for fuel. About 950,000 cords of hardwoods per year are now pulped for use in high-tonnage products such as kraft paper and paperboard, in hardboard, insulation board, roofing, and in finer grade papers. Nearly 400,000 of this is dead chestnut in the form of spent chips from tannin extract plants, but some kraft mills introduce as much as 10 percent of "live" hardwood fiber into high-strength paper and board. Other mills have abandoned hardwoods after unfortunate experiences with poorly controlled ratios of pine and hardwood pulps or with promiscuous mixtures of hardwood species. The greater cost of cutting and processing has been a further handicap. However, hardwood pulps tend to give improved surface, formation, and other properties often desirable in corrugating and liner boards. The International Paper Company now has a hardwood plant for this purpose under construction at Georgetow, South Carolina. Company foresters hope that much of the wood will come from improvement cuttings in mixed pine-hardwood stands, thereby increasing the future yield of pine.

The other possible source of pulpwood--logging and manufacturing waste--is in many respects the most promising. In the South, each cubic foot of forest products ready for the consumer or remanufacturer represents 1.6 cubic feet of sound timber removed from the forest growing stock. Waste produced by logging and primary manufacturing operations in the three states of Virginia, North Carolina, and South Carolina alone amounts to 680 milion cubic feet a year. Eventually, a little is salvaged for pulpwood and a larger portion for fuelwood, but the equivalent of 6 million cords is never utilized. The unused logging waste alone is sufficient to satisfy the demand for pulpwood in these states.

The obstacles to the fuller utilization of waste are largely economic. Perhaps the most important of these is the cost of handling and transportation. Much of the waste is small material widely scattered through the forest or in small concentrations at great numbers of remote plants. Most of that accessibly located is already being used for some purpose: However, certain areas with a heavy concentration of forest industries and good rail and highway communication seem favorable to plant integration, and mechanization might solve many of the problems of handling.

On the second phase, namely forest land acquisition, an excellent start has already been made. Pulp company holdings now totai over 6 million acres. If need be, they could provide over a third of your current needs without over-cutting. In this connection, the question arises as to whether you should attempt to buy enough land to fill 100 percent of your needs. Theoretically, at least, the answer appears to be "no." In the first place, the old warning against "all your eggs in one basket" has no better application than to logging. The wider your cutting operations are scattered, the less chance there is of having your wood supply cut off by weather, labor troubles, and other temporary hindrances. In the second place, there is considerable evidence that it is good business 

to integrate pulpwood production with the production of higher value material--sawlogs, poles, piling, etc.--sales of this material covering a major share of timber-growing costs. And from the standpoint of encouraging better forest practices, the presence of the pulp industry as a ready market for the products of thinnings and stand-improvement cuttings on non-company lands is most desirable. However, land acquisition is a logical safeguard, and the scientific management practiced thereon can serve as an example to other landowners.

Acquiring land and utilizing substitute woods are both projects which could produce positive and easily measurable results within a few years. The third phase of the attack on the wood-supply problem is, by comparison, more complicated and must be sustained for a relatively long period to accomplish its purpose-that is to say, increased production of quality wood on forest land tributary to your mills. To assure a worthwhile increase, the following minimum management requirements must be met: (1) protection from fire, (2) harvest cuttings which reserve mature trees in sufficient number to reseed the area cut over, and (3) intermediate cuttings in young stands to increase their yield. Omitting any one of the three steps will largely nullify the others.

Some progress has already been made in the fields of forest protection and management. For instance, 53 percent of our forest land has been brought under organized protection, and public appropriations for this purpose are being enlarged. Two southern states, South Carolina and Virginia, can now boast 100-percent coverage. Public and private agencies have also planted some two million acres of denuded land. Your own holdings offer an excellent example of the application of management practices. For the most part, they are well cared for. Similar examples of good management are to be found on some lumber-company and other private lands as well as on public forests, but well-managed tracts still comprise only a small portion of forest lands. The area meeting the minimum standards of protection and management probably does not exceed 20 percent of the total.

A potent factor impeding the wider application of management principles is the complex ownership pattern. Nearly 70 percent of the forest is in a million and a half private ownerships of less than 5,000 acres each. It is difficult to reach so vast a number of owners and to convince them that present gain should be deferred in favor of ultimately greater and perpetual profits. Few look beyond the present, and few are financially able to do so. As a result, cutting practices are determined largely by a desire for the maximum immediate return. Generally, they result in heavy over-cutting with haphazard restocking, and, frequently, conversion to low grade hardwoods.

Since it is not probable that the existing ownership pattern will change materially for some time to come, the pulp industry has a considerable stake in the better handling of these small ownerships. In recent years, various public and private agencies, including your own 

Southerm Pulpwood Conservation Association, have been guiding and assisting woodland owners in proper management practices. However, progress has been too slow to prevent continued depletion. These activities must be greatly expanded to obtain increased yields on an ever larger proportion of the forest. They should be supplemented by legislation establishing the minimum standards of cutting needed to prevent further deterioration on those lands not brought under management.

To sum up, the forest resources of the South are gradually deteriorating both in volume and quality. This deterioration is sufficiently advanced to be reflected in sharper competition for wood, and consequently, in rising wood costs. To meet this situation, your industry has already embarked on a land acquisition program. This is a logical step, but it is probably not feasible to seek complete self-sufficiency in this way. As an added safeguard, you should investigate the possibilities of supplementing supplies of pine with wood material less in demand. However, in the final analysis, the problem of pulpwood supply is one phase of the over-all forest problem of the region--namely, to prevent further depletion on a million and a half small ownerships while bringing as many as possible into greater productivity through management such as you practice on your own lands. Since the interests of your industry correspond to those of the general public in this matter, will you lend your full support to such a program? 


